\title{
KEPASTIAN HUKUM DALAM KEPEMILIKAN SATUAN RUMAH SUSUN
}

\author{
Hestining Cholifah \\ Magister Kenotariatan, Fakultas Hukum, Universitas Narotama \\ Email: hestiningcholifah@gmail.com
}

\begin{abstract}
ABSTRAK
Penelitian ini bertujuan untuk mengetahui hubungan hukum para pihak dalam Perjanjian Pengikatan Jual Beli (PPJB) Satuan Rumah Susun dan perlindungan hukum bagi pembeli Satuan Rumah Susun apabila penjual/developer wanprestasi. Penelitian ini merupakan penelitian yang bersifat yuridis normatif yaitu penelitian terhadap hukum yang berada di dalam perundang-undangan yang berlaku di Indonesia. Penelitian ini menitikberatkan pada penelitian dokumen atau kepustakaan yang intinya mencari teori-teori, pandangan yang mempunyai korelasi dan relevan dengan permasalahan yang akan diteliti. Hasil penelitian menunjukkan bahwa hubungan hukum antara para pihak dalam PPJB dimulai sejak adanya penandatangan PPJB maka terjalin hubungan hukum yang menimbulkan hak dan kewajiban pada masing-masing pihak. Perlindungan hukum bagi pembeli Satuan Rumah Susun apabila penjual/developer melakukan wanprestasi adalah melalui arbitrase dengan biaya tanggung renteng oleh para pihak. Ini berarti jika terjadi sengketa antara para pihak mengenai perjanjian jual beli satuan rumah susun, maka penyelesaiannya tidak melalui peradilan umum atau litigasi, tetapi upaya penyelesaiannya ditempuh melalui arbitrase (non litigasi).
\end{abstract}

Kata Kunci: Rumah Susun, Perjanjian Pengikatan Jual Beli, Perlindungan Hukum

\begin{abstract}
This study aimed to determine the legal relationship of the parties in the Agreement on Sale and Purchase (PPJB) Flats and legal protection for buyers of Flat Housing Unit if the seller / developer defaults. This research is a normative juridical research, namely research on laws that are in the legislation in force in Indonesia. This research focused on document research or literature which essentially looks for theories, views that have correlation and are relevant to the problems to be studied. The results of the study indicated that the legal relationship between the parties in the PPJB starts from the signing of the PPJB, so that a legal relationship is established which creates the rights and obligations of each party. Legal protection for buyers of Flat Units if the seller / developer defaults is through arbitration at the cost of joint responsibility by the parties. It meant that if there is a dispute between the parties regarding the sale and purchase agreement unit apartment, the settlement is not through public court or litigation, but the solution is taken through arbitration (non litigation).
\end{abstract}

Key words: Flats, Agreement on Binding of Sale and Purchase, Legal Protection 


\section{PENDAHULUAN}

Rumah adalah tempat tinggal, tempat berlindung dan bernaung bagi setiap orang yang merupakan salah satu kebutuhan primer setelah makanan, minuman dan pakaian bagi manusia. Pembangunan perumahan yang semakin pesat salah satu tujuannya adalah memenuhi kebutuhan primer manusia. Dari tahun ke tahun kebutuhan rumah ini dirasa cukup sangat besar, mengingat pesatnya pertumbuhan penduduk yang merupakan permasalahan utama bagi peningkatan permintaan akan rumah, khususnya di kota-kota besar negara berkembang seperti Indonesia. Sementara kendala yang dihadapi adalah terbatasnya lahan untuk pemukiman di perkotaan. Salah satu alternatif untuk memecahkan kebutuhan pemukiman/perumahan di perkotaan dengan lahan yang sangat terbatas, yaitu dengan membuat model hunian yang dibuat secara vertikal, yaitu berupa bangunan rumah susun.

Ada beberapa istilah dalam penyebutan rumah susun, seperti : rumah susun, apartemen, flat, strata title dan condominium, hal ini biasanya dilihat dari bentuk bangunan dan siapa penghuni dari rumah susun tersebut, misalnya mulai dari yang berkelas, biasa disebut apartemen/ condominium (untuk golongan menengah keatas) maupun yang sederhana yang biasa disebut Rusun (Rumah Susun) untuk golongan menengah kebawah. Namun demikian, apapun istilah-istilah yang ada dalam masyarakat tentang rumah susun tersebut, apakah itu rumah susun, strata title, apartemen, flat dan condominium, yang biasanya dilihat dari bentuk bangunan dan siapa penghuni dari rumah susun tersebut, baik yang berkelas seperti apartemen/condominium maupun yang sederhana yang biasa disebut Rusun (Rumah Susun), dalam bahasa hukumnya tetaplah disebut sebagai "Rumah Susun", karena mengacu pada Undang-Undang Nomor 20 Tahun 2011 Tentang Rumah Susun (UURS), dimana dalam Pasal 1 ayat (1) UURS disebutkan pengertian Rumah Susun, adalah:

"Bangunan gedung bertingkat yang dibangun dalam suatu lingkungan yang terbagi dalam bagian-bagian yang distrukturkan secara fungsional, baik dalam arah horizontal maupun vertikal dan merupakan satuan-satuan yang masing-masing dapat dimiliki dan digunakan secara terpisah terutama untuk tempat hunian yang dilengkapi dengan bagian bersama, benda bersama dan tanah bersama."

Rumah susun sebagai sesuatu yang tergolong baru bagi masyarakat, maka cukup banyak timbul permasalahan yang menyangkut pengelolaan rumah susun. Permasalahan penghunian bisa timbul karena menghuni rumah susun sebagai bentuk budaya baru yang membutuhkan waktu untuk penyesuaian.

Hubungan hukum antara pengembang, pengelola, penghuni dan pengurus PPPSRS (Perhimpunan Pemilik dan Penghuni Satuan Rumah Susun), yang terkadang tidak harmonis, 
dapat menimbulkan ketidak nyamanan dalam penghunian rumah susun. Demikian juga untuk perlindungan terhadap pemilik/ penghuni satuan rumah susun sebagai konsumen/pembeli satuan rumah susun hingga saat ini masih lemah, dikarenakan dalam perjanjian jual beli/sewa menyewa rumah susun yg dibuat dalam bentuk baku tersebut lebih diutamakan kepentingan pihak yang menyewakan/pemilik dari pada pihak penyewa/penghuni rumah susun. Belum lagi adanya developer yang melakukan wanprestasi dengan berbagai alasan-alasan yang tentunya sangat merugikan bagi pembeli rumah susun, seperti penyelesaian pembangunan yang mundur dari jadwal yang telah ditentukan, ataupun kualitas rumah susun yang ternyata tidak sesuai dengan apa yang diperjanjikan, dimana bila terjadi sengketa, maka penyelesaiannya selalu melalui musyawarah, karena hal ini sudah diatur dalam perjanjian jual beli/sewa menyewa satuan rumah susun tersebut, namun bila melalui jalur non litigasi tersebut tidak dapat menyelesaikan sengketa, maka tidak menutup kemungkinan untuk menyelesaikan sengketa melalui jalur litigasi, yaitu dengan mengajukan gugatan ke peradilan umum.

\section{RUMUSAN MASALAH}

1. Apa hubungan hukum antara penjual (developer) dan pembeli dalam Perjanjian Pengikatan Jual Beli Satuan Rumah Susun?

2. Apa bentuk perlindungan hukum bagi pembeli Satuan Rumah Susun apabila penjual/developer wanprestasi?

\section{METODE PENELITIAN}

Penelitian ini menggunakan metode penelitian hukum normatif yang dilakukan untuk mencari pemecahan masalah atas permasalahan hukum yang ada. Pendekatan penelitian yang digunakan adalah pendekatan undang-undang (statute approach) dan pendekatan konseptual (conceptual approach).

\section{PEMBAHASAN}

Hubungan Hukum Penjual Dan Pembeli Dalam Perjanjian Pengikatan Jual Beli Satuan Rumah Susun

Rumah susun dibangun sebagai upaya memenuhi kebutuhan masyarakat akan hunian yang layak dalam lingkungan yang sehat, dan merupakan salah satu alternatif pemecahan masalah dalam hal pengadaan lahan yang sangat sulit didapat, khususnya diwilayah kota-kota 
besar dinegara berkembang yang sangat padat penduduknya akibat banyaknya urbanisasi dikota-kota besar seperti kota Jakarta dan Surabaya.

Secara sederhana pelaku dalam rumah susun terbagi dalam empat (4) agen, yakni: ${ }^{1}$

1. Pengembang (developer) yakni seseorang atau perusahaan yang mengharapkan keuntungan dengan kegiatan pengembangan rumah susun ;

2. Pengguna (user), seseorang atau perusahaan yang memperoleh keuntungan dengan memanfaatkan atau memiliki rumah susun ;

3. Investor, seseorang atau perusahaan yang mengharapkan keuntungan dari modal yang ditanamkan untuk berinvestasi rumah susun.

4. Spekulator, yakni seseorang atau perusahaan yang memperoleh keuntungan dari spekulasi penempatan modal dalam investasi Rumah Susun.

Selain itu masih ada beberapa pihak yang terkait yang terlibat dalam dunia pemasaran rumah susun, seperti banker, Notaris sebagai pembuat PPJB/AJBnya, pengacara atau konsultan hukum, pihak asuransi, instansi-instansi terkait dan lain-lain.

Menurut peraturan perundangan, para pihak yang terlibat dalam pembangunan dan pengelolaan Rumah Susun adalah $:^{2}$

1. Penyelenggaraan pembangunan, dalam hal ini Pengembang;

2. Perhimpunan penghuni, yang akan dibentuk para penghuni (owner unit) dengan dibantu oleh penyelenggara pembangunan dan dituangkan dalam suatu Anggaran Dasar dan Anggaran Rumah Tangga yang wajib dipatuhi oleh para penghuni / pemilik;

3. Badan Pengelola, yang akan ditunjuk oleh perhimpunan penghuni untuk mengelola Rumah Susun tersebut dengan upah dan biaya-biaya yang akan disetujui oleh Rapat Umum Anggota Perhimpunan penghuni. Badan pengelola ini dapat saja dibentuk oleh perhimpunan sendiri, tetapi lazimnya pengelolaan diserahkan kepada properti manajemen yang profesional;

4. Penghuni, dalam hal ini para pemilik unit sarusun yang akan menjadi anggota Perhimpunan Penghuni dan memiliki hak suara dalam menentukan jalannya pengelolaan.

Hubungan Hukum adalah hubungan yang menimbulkan akibat hukum, akibat hukum disebabkan karena timbulnya hak dan kewajiban, dimana hak merupakan suatu kenikmatan,

\footnotetext{
${ }^{1}$ Adrian Sutedi, Hukum Rumah Susun \& Apartemen, Jakarta, Sinar Grafika, Cetakan I, Nopember 2010, hal. 9

${ }^{2}$ Hatta Isnaini Wahyu Utomo, "Hukum Tanah Nasional : Bahan Diskusi Dalam Menghadapi Ujian Pejabat Pembuat Akta Tanah 2017”, Makalah, disampaikan pada acara Belajar Bareng Alumni, Universitas Narotama, 22 Oktober 2017, hal. 53
} 
sedangkan kewajiban merupakan beban. ${ }^{3}$ Hubungan hukum dari perjanjian menimbulkan suatu perikatan, karena perjanjian tersebut mengikat pada para pihak yang terlibat didalamnya, sebagaimana disebutkan dalam Pasal 1338 ayat (1) BW, yang menyebutkan bahwa semua perjanjian yang dibuat secara sah berlaku sebagai undang-undang bagi mereka yang membuatnya. Karena itulah mengapa perjanjian pengikatan jual beli harus dibuat secara otentik yaitu dibuat dihadapan pejabat yang berwenang. Untuk itu pula perlu diperhatikan mengenai syarat-syarat sahnya suatu perjanjian, sebagaimana diatur dalam Pasal 1320 BW, yaitu : kesepakatan, kecakapan untuk membuat suatu perikatan, suatu hal tertentu dan suatu sebab yang halal.

Untuk memiliki satuan rumah susun dapat dilakukan dengan perjanjian jual beli, dimana proses jual beli sarusun yang dilakukan sebelum pembangunan rumah susun selesai, melalui suatu tindakan hukum dengan membuat suatu perjanjian awal yaitu Perjanjian Pengikatan Jual Beli (PPJB) yang dibuat dihadapan Notaris, sebagaimana diatur di dalam Pasal 43 ayat (1) UURS, tentunya setelah memenuhi persyaratan sebagaimana diatur dalam Pasal 43 ayat (2) UURS. Dengan dibuatnya perjanjian ini, maka mulailah terjalin hubungan hukum antara pengembang (developer) dan pembeli (penghuni) yang menimbulkan hak dan kewajiban pada masing-masing pihak.

PPJB yang dibuat dengan tujuan untuk mengamankan kepentingan penjual/ Pengembang/developer dan calon pembeli satuan rumah susun/ Pemesan dan merupakan salah satu kekuatan hukum sekaligus jaminan hukum pada saat membeli rumah, maka dirasakan perlunya pengaturan secara khusus mengenai pedoman perikatan jual beli SRS yang kemudian dituangkan dalam Kepmenpera No. 11/KPTS/1994 tentang Pedoman Perikatan Jual Beli Satuan Rumah Susun. ${ }^{4}$

Namun pada umumnya perjanjian jual beli atau sewa menyewa pada suatu perumahan, bila kita perhatikan tercantum beberapa klausula baku yang seolah menjadi baku dan sudah lazim dipergunakan dalam perjanjian jual beli yang telah dipersiapkan terlebih dulu oleh developer. Yang dimaksud Klausula baku menurut Undang-Undang Nomor 8 Tahun 1999 Tentang Perlindungan Konsumen (UUPK) adalah setiap aturan atau ketentuan dan syarat-syarat yang telah dipersiapkan dan ditetapkan terlebih dahulu secara sepihak oleh

\footnotetext{
${ }^{3}$ Burhanudin Ali SDB \& Nathanilea Stg, 60 Contoh Perjanjian (Kontrak), Jakarta, Hi-Fest Publishing, Cetakan III, 2009, hal. 14

${ }^{4}$ Hatta Isnaini Wahyu Utomo, Op.Cit., hal. 54
} 
pelaku usaha yang dituangkan dalam suatu dokumen dan/atau perjanjian yang mengikat dan wajib dipenuhi oleh konsumen.

Klausula baku merupakan aturan sepihak dalam kuitansi, faktur/bon, perjanjian, atau dokumen lainnya dalam transaksi jual beli yang sangat merugikan konsumen. Dibuatnya klausula baku menyebabkan posisi konsumen sangat lemah dibandingkan dengan pelaku usaha. Banyak konsumen yang belum mengetahui tentang klausula baku yang terjadi dalam jual-beli rumah. UUPK melarang adanya klausula baku karena mengandung delapan daftar negatif, diantaranya karena isinya mengurangi, membatasi, menghapuskan kewajiban atau tanggungjawab pelaku usaha dan isinya menciptakan kewajiban atau tanggungjawab yang dibebankan pada konsumen. Pencantuman klausula baku dalam dokumen promosi dan transaksi diperbolehkan sepanjang tidak bertentangan dengan Undang-Undang.

Rumah susun dalam hukum Indonesia merupakan rumah yang dibentuk dengan sistem condominium, sebagaimana ditemukan dalam penjelasan umum Peraturan Pemerintah Nomor 4 Tahun 1988 Tentang Rumah Susun, yang menyebutkan "Sistem pemilikan perseorangan dan hak bersama (condominium)".

Dalam sistem condominium ini terdapat pemilikan individual atas satuan rumah susun yang merupakan hak penghuni. Disamping itu terdapat hak pemilikan bersama atas tanah dimana bangunan tersebut terletak (Common areas), hak milik bersama atas sarana-sarana bangunan (common elements) misal corridors, lift, instalasi listrik, kebun, tempat rekreasi, kolam renang, lobi, garasi dan lain sebagainya yang dapat digunakan bersama oleh para penghuni. $^{5}$

Sistem condominium ini dapat dijelaskan dalam Pasal 1 ayat (4), (5) dan (6) UURS, yang memuat tentang pengertian tanah bersama, bagian bersama dan benda bersama. Menurut Oloan Sitorus dan Balans Sebayang ada 3 (tiga) bentuk sistem pemilikan, yaitu : ${ }^{6}$

1. Sistem pemilikan perseorangan

2. Sistem pemilikan bersama yang terikat

3. Sistem pemilikan perseorangan yang sekaligus dilengkapi dengan sistem pemilikan bersama yang bebas (condominium).

Bila dilihat dari ketiga bentuk sistem kepemilikan tersebut diatas, maka sistem kepemilikan rumah susun jelas merupakan kategori sistem pemilikan ketiga (huruf c).

\footnotetext{
${ }^{5}$ M.Rizal Alif, Analisis Kepemilikan Hak Atas Tanah Satuan Rumah Susun di Dalam Kerangka Hukum Benda, Bandung, Nuansa Aulia, Cetakan I, Maret 2009, hal. 19

6 Oloan Sitorus dan Balans Sebayang, Kondominium dan Permasalahannya, Yogyakarta, Mitra Kebijakan Tanah Indonesia, Cetakan Pertama, 1998, hal. 18
} 
Guna memberikan kedudukan atau sebagai dasar untuk memberikan kedudukan sebagai benda tak bergerak yang dapat menjadi objek pemilikan serta untuk memberikan landasan bagi sistem pemilikan atas SRS diwajibkan adanya pengaturan atas bagian bangunan yang masing-masing dapat dimiliki secara terpisah yang mengandung hak atas bagian bersama, benda bersama dan tanah bersama, dikenal dengan pemisahan. ${ }^{7}$ Pemisahan menjelaskan bagian-bagian satuan rumah susun dalam bentuk gambar dan uraian yang dibuat sebelum pelaksanaan pembangunan rumah susun, yang disahkan oleh instansi yang berwenang sesuai dengan peraturan perundang-undangan yang berlaku, yang merupakan kewajiban penyelenggara pembangunan (Pasal 25 ayat (1) UURS).

\section{Perlindungan Hukum Bagi Pembeli Satuan Rumah Susun Apabila Penjual Wanprestasi}

Perjanjian jual beli adalah suatu perjanjian dimana pihak yang satu menyanggupi akan menyerahkan hak milik atas suatu barang sedangkan pihak lainnya menyanggupi akan membayar sejumlah uang sebagaimana harganya. ${ }^{8}$ Dari pengertian ini maka perjanjian jual beli merupakan perjanjian timbal balik yang melahirkan hak dan kewajiban bagi penjual dan pembeli.

Hak dan kewajiban bagi penjual dan pembeli timbul dari adanya hubungan hukum, dimana hubungan hukum ini bersumber dari adanya perjanjian yang telah dibuat oleh kedua belah pihak, adapun unsur-unsur yang harus ada dalam perjanjian adalah sebagai berikut : ${ }^{9}$

1. Adanya kaidah hukum

2. Subyek hukum

3. Adanya prestasi

4. Kata Sepakat

5. Akibat hukum

Dalam perjanjian jual beli secara umum hak dan kewajiban penjual dan pembeli adalah:

1. Menurut Pasal 1474 BW, penjual mempunyai dua kewajiban utama, yaitu:

a. Menyerahkan barangnya;

b. Menanggung barang yang dijual ;

\footnotetext{
${ }^{7}$ Imam Sutikno, Beberapa Permasalahan Tentang Rumah Susun, Jakarta, Pelita Ilmu, 2007, hal. 65

${ }^{8}$ Subekti, Hukum Perjanjian, Jakarta, Intermasa, Cetakan 21, 2005, hal. 161-162

${ }^{9}$ Burhanudin Ali SDB \& Nathanilea Stg, Op.Cit, hal. 14
} 
Penanggungan yang menjadi kewajiban si penjual terhadap si pembeli menurut Pasal 1491 BW adalah untuk menjamin dua hal, yaitu:

1) Menjamin penguasaan benda yang dijual secara aman dan tenteram.

2) Menjamin tidak adanya cacad barang yang tersembunyi.

Disamping itu, menurut ketentuan Pasal 1473 BW, seorang penjual diwajibkan menyatakan dengan tegas untuk apa ia mengikatkan dirinya dan segala janji yang tidak terang akan ditafsir untuk kerugiannya.

2. Kewajiban utama untuk pembeli adalah membayar harga pembelian, pada waktu mana dan di tempat sebagaimana ditetapkan menurut perjanjian. Jika pada waktu membuat perjanjian tidak ditetapkan tempat dan waktu pembayaran, maka si pembeli harus membayar di tempat dan pada waktu di mana penyerahan harus dilakukan. Apabila si pembeli tidak membayar harga pembelian, maka si penjual dapat menuntut pembatalan perjanjian. ${ }^{10}$

Akibat hukum yang timbul dari adanya hubungan hukum yang kemudian memunculkan hak dan kewajiban. Dimana hak merupakan kenikmatan sedangkan kewajiban merupakan beban. ${ }^{11}$ Maka timbal balik dari pada kewajiban-kewajiban penjual dan pembeli tersebut adalah hak yang harus diterima oleh penjual dan pembeli. Hak penjual adalah menerima uang dari pembeli sebagaimana yang telah disepakati dan hak pembeli adalah menerima apa yang dikehendaki dari yang diperjanjikan. Hak dan kewajiban bagi para pihak (penjual dan pembeli) dalam jual beli SRS sudah tertera dalam PPJB yang pembuatannya berdasarkan Kepmenpera No. 9/1995.

Wanprestasi dari developer bisa jadi berawal dari mulai masa promosi, yaitu saat dibuatnya brosur-brosur atau iklan-iklan dari berbagai media, bisa juga berawal dari perjanjian perikatan jual beli yang dibuat.

Bentuk-bentuk wanprestasi pengembang/developer, antara lain dapat berupa :

1. Gagal atau terlambat membangun satuan rumah susun ;

2. Bangunan disengketakan karena status tanah ;

3. Sertifikat masih berbentuk sertifikat induk dan bank tidak bersedia untuk dilakukannya pemecahan sertifikat induk ;

4. Pengembang bangkrut sehingga sertifikat yang digunakan sebagai jaminan tidak dapat dikeluarkan oleh bank.

\footnotetext{
${ }^{10}$ P.N.H.Simanjuntak, Pokok-Pokok Hukum Perdata Indonesia, Jakarta, Djambatan, 1999, hal. 356

${ }^{11}$ Burhanudin Ali SDB \& Nathaniela Stg., Op.Cit., hal. 14
} 
Demi menjamin perlindungan hukum bagi pembeli satuan rumah susun sebagai konsumen, maka di dalam perjanjian pengikatan jual beli selain dicantumkan secara tegas : harga, cara pembayaran, spesifikasi satuan rumah susun yang dibeli, hak dan kewajiban penjual dan pembeli, klausula pembatalan jual beli, jaminan penjual atas mutu dan status yang jelas satuan rumah susun, klausula ganti rugi, masa berlakunya perjanjian, juga di cantumkan klausula tentang penyelesaian perselisihan bila ada perselisihan apakah diselesaikan di peradilan umum atau di Badan Arbitrase.

\section{PENUTUP}

\section{Kesimpulan}

Hubungan hukum antara penjual (developer) dan pembeli dalam PPJB adalah sebagai penjual dan pembeli, dimana developer/pengembang sebagai penjual SRS dan pembeli adalah sebagai pembeli SRS dengan didasari hukum perjanjian jual beli yang diatur didalam Kitab Undang-Undang Hukum Perdata (BW). PPJB yang dibuat dengan tujuan untuk mengamankan kepentingan penjual/pengembang/developer dan calon pembeli SRS/pemesan dan merupakan salah satu kekuatan hukum sekaligus jaminan hukum pada saat membeli SRS, maka harus sesuai dengan Kepmenpera No. 11/KPTS/1994. Perlindungan hukum bagi konsumen dapat berupa suatu tuntutan atas PPJB yang telah dibuat dan ditandatangani, dimana tuntutan tersebut dapat diajukan kepada Badan Arbitrase dan atau Peradilan Umum setempat, penyelesaian perselisihan melalui Badan Arbitrase sesuai dengan Permenpera No. 11/KPTS/1994.

\section{Saran}

Perlu adanya upaya dari pemerintah maupun lembaga konsumen untuk sosialisasi dan memberikan kesadaran kepada konsumen agar lebih cermat dalam mengadakan hubungan hukum dengan developer dalam pembelian rumah susun agar dapat melindungi kepentingan para pihak.

\section{DAFTAR PUSTAKA}

Adrian Sutedi, Hukum Rumah Susun \& Apartemen, Jakarta, Sinar Grafika, Cetakan I, Nopember 2010

Burhanudin Ali SDB \& Nathanilea Stg, 60 Contoh Perjanjian (Kontrak), Jakarta, Hi-Fest Publishing, Cetakan III, 2009 
Hatta Isnaini Wahyu Utomo, "Hukum Tanah Nasional : Bahan Diskusi Dalam Menghadapi Ujian Pejabat Pembuat Akta Tanah 2017", Makalah, disampaikan pada acara Belajar Bareng Alumni, Universitas Narotama, 22 Oktober 2017

Imam Sutikno, Beberapa Permasalahan Tentang Rumah Susun, Jakarta, Pelita Ilmu, 2007

M.Rizal Alif, Analisis Kepemilikan Hak Atas Tanah Satuan Rumah Susun di Dalam Kerangka Hukum Benda, Bandung, Nuansa Aulia, Cetakan I, Maret 2009

Oloan Sitorus dan Balans Sebayang, Kondominium dan Permasalahannya, Yogyakarta, Mitra Kebijakan Tanah Indonesia, Cetakan Pertama, 1998

P.N.H.Simanjuntak, Pokok-Pokok Hukum Perdata Indonesia, Jakarta, Djambatan, 1999

Subekti, Hukum Perjanjian, Jakarta, Intermasa, Cetakan 21, 2005 